\title{
The Relationship between Economic Growth and Government Expenditure: Evidence from Sudan
}

\author{
Mohame Abdel Rahman Salih ${ }^{1}$ \\ ${ }^{1}$ College of Business Administration, Taibah University, Medina, Kingdom of Saudi Arabia \\ Correspondence: Mohamed Abdel Rahman Salih, College of Business Administration, Taibah University, P. O. \\ Box 344, Medina, Kingdom of Saudi Arabia. Tel: 966-599-321-580. E-mail: msalih@taibahu.edu.sa
}

Received: May 2, 2012

Accepted: May 11, $2012 \quad$ Online Published: July 1, 2012

doi:10.5539/ibr.v5n8p40

URL: http://dx.doi.org/10.5539/ibr.v5n8p40

\begin{abstract}
In the economic literature, there are two opposing views on the relationship between economic growth and the size of the government. The Wagner hypothesis states that as the economy grows so does the size of the public sector. This is in contrast to the Keynesian view that the growth of government expenditure results in the growth of GDP. The Wagner hypothesis was tested for different countries and the results were conflicting. The primary objective of this paper is test the Wagner hypothesis in the context of the Sudan for the period 1970-2010. The methodology used is cointegration, causality, and error correction model (ECM). The results for the Sudan indicate that the data for the period considered supports the Wagner's hypothesis.
\end{abstract}

Keywords: Wagner hypothesis, Keynesian model, economic growth, government expenditure, Sudan

\section{Introduction}

In the economic literature, there are two opposing views on the relationship between economic growth and the size of the public sector. The Wagner hypothesis states that as the economy grows so does the size of the public sector. This is in contrast to the Keynesian view that the growth of government expenditure results in the growth of output. The Wagner hypothesis was tested for different countries and the results were quite conflicting. For example, Ghali (1997) uses vector autoregressive (VAR) analysis and finds inconsistent results that government spending has a positive impact on Saudi Arabia's per capita growth of output. Landau (1983), using a cross-section study of 104 countries, finds a negative relationship between the growth rate of real per capita GDP and the share of government consumption expenditure to GDP. Ramayandi (2003), using a time series data on Indonesia for the period 1969-1999, finds the share of government consumption spending to GDP decreases economic growth. His results also show that public investment negatively affect economic growth. Kormendi and Meguire (1985), using post-war data from 47 countries, find no significant relationship between the average growth rates of real GDP and the average growth rate or levels of the share of government consumption spending in GDP. Sáez and García (2006) find a positive relationship between government spending and economic growth using data from the EU-15 countries. Grier and Tullock (1987), using panel data, find a negative relationship between the growth rate of real GDP and the share of government spending to GDP. Barro (1991), using a sample of 98 countries for the period 1970-1985, finds a negative relationship between the GDP growth rate and the share of government consumption expenditure to GDP. His results also show that the share of public investment to GDP is positively related to the growth rate of GDP. However, this finding fails to be statistically significant. Hsieh and Lai (1994), using data from the G-7 countries, find no evidence of a relationship between the share of government spending to GDP and per capita GDP growth.

The primary objective of this paper is to empirically assess the relationship between economic growth and government expenditure in the context of Sudan for the period 1970-2010. Understanding the relationship between different macroeconomic variables is of fundamental importance, especially to policymakers. This understanding ensures effective designing and implementation of macroeconomic stabilization policies. To the best of my knowledge, there has been little empirical analysis of the relationship between the public expenditure and economic growth in the case of Sudan. This papers attempts to fill this gap by addressing the relationship between these two important macroeconomic variables. 
The remainder of the paper is organized as follows. Section 2 describes the methodology employed. Section 3 presents data used, results obtained, and discussion. Section 4 wraps the paper up with summary and conclusion.

\section{Methodology}

In time series analysis, the properties of standard estimation and testing techniques depend on the assumption that the variables under consideration are stationary. Regression analysis conducted on non-stationary series can produce misleading results. This is referred to as "spurious regression" by Granger and Newbold (1974). Indeed, they maintain that spurious regression "produces statistically significant results between series that contain a trend and otherwise random". Phillips (1986) shows that when the series are not stationary, the ordinary least squares (OLS) estimator is not consistent and the $\mathrm{t}$ and $\mathrm{F}$ statistics do not follow the known standard distributions.

If the mean and variance of a series are constant over time, then the series is said to be stationary i.e. no unit root. If the series is not stationary, differencing techniques are normally used to transform a series from non-stationary to stationary. In most cases, the first difference of a non-stationary series will transform it into stationary. If a series is stationary without the process of differencing, it is denoted by $\mathrm{I}(0)$, or integrated of order 0 . On the other hand, if a series is stationary after the first difference, it is denoted by I(1), or integrated of order 1 . In general, if a series is stationary after the $p^{\text {th }}$ differencing, then it is denoted by $\mathrm{I}(p)$, or integrated of order $p$. Several techniques for testing stationarity are proposed in the literature. The most commonly used are the augmented Dickey-Fuller (ADF) test and the Phillip-Perron (PP) test.

\subsection{The ADF and PP Tests}

The ADF and PP tests are used to test the stationarity of a series. In equations (1) and (2) below the series of interest is $x$. The symbol $\Delta$ indicates the first difference of the series $x, \mathrm{t}$ in equation (2) is a time trend, and $\mathrm{k}$ is the number of lagged variables that are used to ensure the error term e is white noise. The optimal number of lags is determined, among others ways, by either using the Akaike Information Criterion (AIC) or the significance of the estimated coefficients of these lagged variables.

$$
\begin{gathered}
\Delta x_{t}=\alpha_{1}+\gamma_{1} x_{t-1}+\sum_{i=1}^{k} c_{1 i} \Delta x_{t-i}+e_{1 t} \\
\Delta x_{t}=\alpha_{2}+\gamma_{2} x_{t-1}+\beta t+\sum_{i=1}^{k} c_{2 i} \Delta x_{t-i}+e_{2 t}
\end{gathered}
$$

The ADF technique tests the null hypothesis $\gamma_{i}=0$ against the alternative hypothesis $\gamma_{i}<0(i=1,2)$. Rejection of the null hypothesis is an indication that the series $x$ is stationary. In equation (1) the alternative hypothesis indicates the series is a mean-stationary and in equation (2) it indicates the series is a trend-stationary.

The ADF test has been criticized because it does not allow for the presence of structural breaks. It is possible for the ADF test to erroneously reject the unit root hypothesis if the series has structural breaks. Perron (1989) shows that "failing to allow for an existing break, leads to a bias that reduces the ability to reject the unit root hypothesis, which is otherwise false". Several authors have proposed to overcome this problem by endogenously determining the breaks. See e.g. Zivot and Andrews (1992), Perron and Vogelsang (1992), Perron (1997), Lumsdaine and Papell (1997), Clements et al (1998), and Lee and Strazicich (2003).

\subsection{Unit Root Test with Structural Breaks}

As indicated above, the ADF test does not allow for the presence of structural breaks. Zivot and Andrews (1992) propose a procedure that allows for one structural break. They specify three models similar to (3)-(5) below to test unit root with one structural break.

$$
\begin{gathered}
\Delta x_{t}=\alpha_{1}+\gamma_{1} x_{t-1}+\beta_{1} t+\delta_{1} D U_{t}+\sum_{i=1}^{k} c_{1 i} \Delta x_{t-i}+e_{1 t} \\
\Delta x_{t}=\alpha_{2}+\gamma_{2} x_{t-1}+\beta_{2} t+\theta_{2} D T_{t}+\sum_{i=1}^{k} c_{2 i} \Delta x_{t-i}+e_{2 t} \\
\Delta x_{t}=\alpha_{3}+\gamma_{3} x_{t-1}+\beta_{3} t+\delta_{3} D U_{t}+\theta_{3} D T_{t}+\sum_{i=1}^{k} c_{3 i} \Delta x_{t-i}+e_{3 t}
\end{gathered}
$$

Where $D U_{t}$ is a dummy variable for a mean shift occurring at each possible break date (TB), and $D T_{t}$ is the corresponding trend shift. These two variables are defined as follows:

$$
D U_{t}=\left\{\begin{array}{lc}
1 & \text { if } t>T B \\
0 & \text { Otherwise }
\end{array} \text {; and } D T_{t}=\left\{\begin{array}{cc}
t-T B & \text { if } t>T B \\
0 & \text { otherwise }
\end{array}\right.\right.
$$

Again, as is the case with the ADF test, the null hypothesis in the above three models (3)-(5) is $\gamma_{i}=0$ against the alternative hypothesis $\gamma_{i}<0(i=1,2$, and 3). Except for trimmed end points, Zivot and Andrews (1992) 
regard every date as a possible break date. A regression is run for every possible break date sequentially. The date which corresponds with the least $t$ value of the estimated parameter $\widehat{\gamma}_{l}$ is chosen as the break date.

\subsection{Engle-Granger and Johansen's Cointegration Tests}

The cointegration test simply tests whether a long run relationship exists between the non-stationary series. To carry out the cointegration test using Engle-Granger and Johansen's methods, both series must be integrated of the same order. After verifying that both series are I(1), we carry out the Engle-Granger and Johansen's tests. Engle and Granger (1987) propose estimating, in the first step, an equation of the following form:

$$
y_{t}=\alpha+\beta x_{t}+u_{t}
$$

The second step tests whether the residuals series $\hat{u}_{t}=y_{t}-\hat{\alpha}-\hat{\beta} x_{t}$ is stationary. In this test, the null hypothesis is "No Cointegration". If the null hypothesis is rejected, then the two series are cointegrated. Alternatively, one can use the Johansen's cointegration test (Johansen, 1991). Johansen's method starts with a vector auto regression (VAR) model of order $k$ as follows:

$$
y_{t}=\gamma+\sum_{i=1}^{k} A_{i} y_{t-i}+u_{t}
$$

Equation (8) can be written as follows:

$$
\Delta y_{t}=\gamma+\Pi y_{t-1}+\sum_{i=1}^{k-1} \Gamma_{i} \Delta y_{t-i}+u_{t}
$$

where $y_{t}$ is an (mx1) vector of variables that are I(1), $\Pi=\sum_{i=1}^{k} A_{i}-\mathrm{I}$, and $\Gamma_{i}=-\sum_{j=i+1}^{k} A_{j}$. If $\Pi(\mathrm{mxm})$ is a zero matrix, then there is no cointegration between the variables. If $\Pi$ has a full rank $\mathrm{m}$, then the variables must be stationary. On the other hand, if $\Pi$ has less than full rank $(\mathrm{r}<\mathrm{m})$, then there exists (mxr) matrices $\alpha$ and $\beta$ (each with rank r) such that $\Pi=\alpha \beta^{\prime}$ and $\beta^{\prime} y_{t}$ is stationary. $\beta$ is the cointegration matrix and $\alpha$ is the speed of adjustment towards long run equilibrium. The number of cointegrating relationships is equivalent to $\mathrm{r}$. Johansen (1991) proposes two likelihood ratio test methods - the trace test and the maximum eigenvalue test. These are given below.

$\lambda_{\text {trace }}=-n \sum_{i=r+1}^{m} \ln \left(1-\hat{\lambda}_{i}\right)$ and $\lambda_{\max }=-n \ln \left(1-\hat{\lambda}_{r+1}\right), n$ is the sample size and $\hat{\lambda}_{i}$ is the $i^{\text {th }}$ largest canonical correlation between $y_{t-1}$ and $\Delta y_{t}$.

\subsection{The ECM and Granger Causality Test}

Once we have verified that the series have a long run relationship (cointegrated), we can proceed with the ECM. Let the two series under consideration be denoted by $x_{t}$ and $y_{t}$ then the ECM of the following form can be specified:

$$
\begin{aligned}
\Delta x_{t} & =\alpha_{0}+\alpha_{1} \hat{v}_{t-1}+\sum_{i=1}^{k} a_{i} \Delta x_{t-i}+\sum_{i=1}^{k} b_{i} \Delta y_{t-i}+u_{t} \\
\Delta y_{t} & =\beta_{0}+\beta_{1} \widehat{w}_{t-1}+\sum_{i=1}^{k} c_{i} \Delta x_{t-i}+\sum_{i=1}^{k} d_{i} \Delta y_{t-i}+u_{t}
\end{aligned}
$$

where $\hat{v}$ and $\widehat{w}$ are the error correction terms. $\hat{v}$ is the value of the residuals from the regression of $x$ on $y$ using the OLS estimation method and $\widehat{w}$ is the value of the residuals from the regression of $y$ on $x$ using the OLS estimation method. These regressions are similar to what we have seen in equation (7) above. According to Engle and Granger (1987), within the ECM formulations (10) and (11), $x$ does not Granger cause $y$ if $\beta_{1}=0$ and $c_{i}=0, \forall_{i}$. Similarly, $y$ does not Granger cause $x$ if $\alpha_{1}=0$ and $b_{i}=0, \forall_{i}$.

\section{Data, Results, and Discussion}

In this section the data used is described and the results obtained are presented.

\subsection{Data}

Data on the government expenditure and the Gross Domestic Product (GDP) is obtained from the United Nations' statistics division. The two variables are measured in US dollars and are expressed in real terms by deflating them by the GDP deflator (base year $=2005$ ).

In this paper we use the per capita real GDP and the share of government expenditure to GDP. These two variables are further transformed into natural logarithm to eliminate any serial correlation that might be present and they are denoted below by $\mathrm{Y}$ and $\mathrm{G}$, respectively.

\subsection{Results and Discussion}

In this section we display the results of the various tests conducted. Each test uses at least two different methods in order to reach a definite result. To have a feel of the data, the following graph shows the two variables in level and first difference. From the graph it is clear that $\mathrm{G}$ and $\mathrm{Y}$ are non-stationary and it is also clear that $\mathrm{G}$ is mean stationary in first difference and $\mathrm{Y}$ is trend stationary in first difference. 


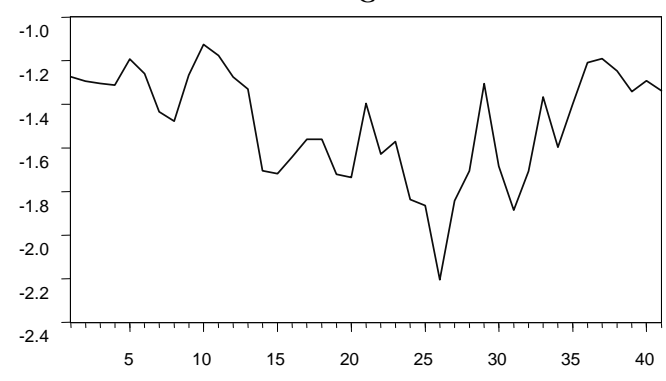

Y

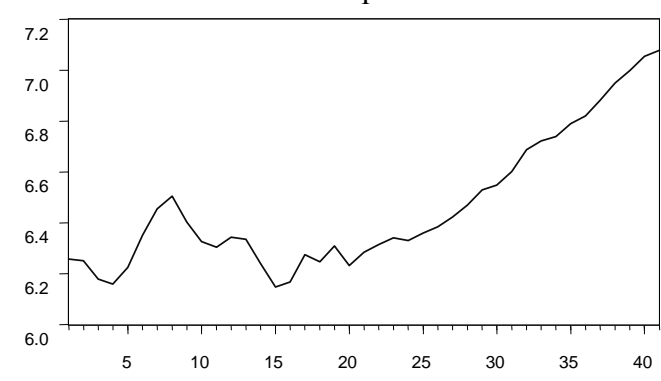

Fisit Difference of G

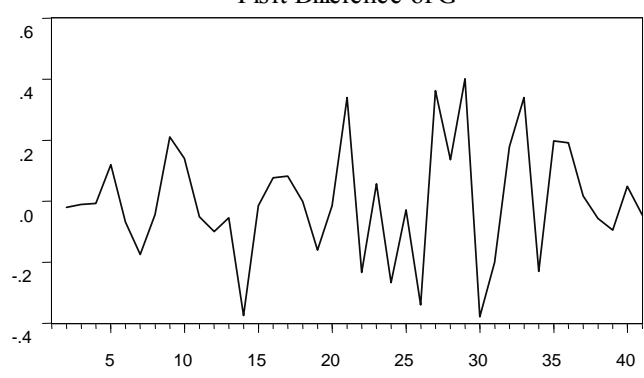

First Difference of Y

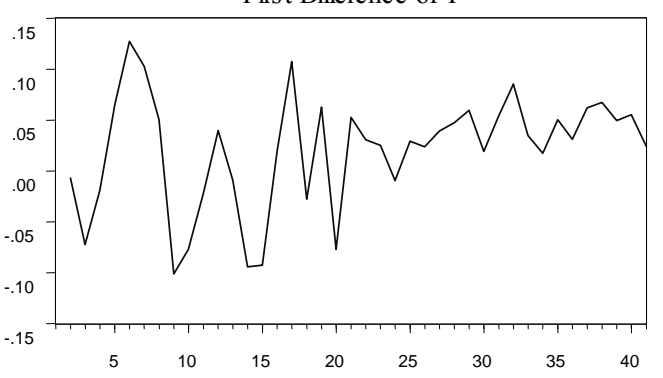

\subsubsection{Unit Root Tests}

Figure 1. G and $\mathrm{Y}$ in level and first difference

The results of the three unit root tests considered in the methodology section are shown below. Table 1 displays the results of the ADF and PP tests. The results indicate that the series Y and G are non-stationary at levels but they are stationary when we take the first difference, i.e. both series are I(1). The stationarity results (with intercept and trend) are significant at the 5\% level or lower except for $\Delta \mathrm{Y}$ with intercept.

Table 1. Augmented Dickey-Fuller (ADF) and Phillips-Perron (PP) Tests

\begin{tabular}{lllll}
\hline \multirow{2}{*}{ Variable } & ADF & & PP & Intercept \& Trend \\
\cline { 2 - 5 } & Intercept & Intercept \& Trend & Intercept & -2.4614 \\
\hline $\mathrm{G}$ & -2.6133 & -2.5187 & -2.5556 & $-13.6327^{* *}$ \\
$\Delta \mathrm{G}$ & $-6.8956^{* *}$ & $-6.8582^{* *}$ & $-10.6926^{* *}$ & -0.7317 \\
$\mathrm{Y}$ & 1.2640 & 0.0132 & 1.4646 & $-5.6209^{* *}$ \\
$\Delta \mathrm{Y}$ & -1.5915 & $-5.1124^{* *}$ & $-4.0776^{* *}$ & -50 \\
\hline
\end{tabular}

Note: ${ }^{* *}\left(^{*}\right)$ indicates significant at the level of significance $1 \%$ or lower $(5 \%$ or lower).

Table 2 shows the results of the Zivot and Andrews unit root test with one structural break. Again the two series are stationary at the first difference with one break. These results establish the fact the series $G$ and $Y$ are stationary at first difference.

Table 2. Zivot and Andrews Unit Root Test with One Endogenous Structural Break

\begin{tabular}{lllllll}
\hline \multirow{2}{*}{ Variable } & Intercept & \multicolumn{3}{c}{ Trend } & \multicolumn{3}{c}{ Both } \\
\cline { 2 - 7 } & TB & t-Statistic & TB & t-Statistic & TB & t-Statistic \\
\hline $\mathrm{G}$ & 2002 & -4.2051 & 1996 & $-4.4648^{*}$ & 1993 & -4.6534 \\
$\Delta \mathrm{G}$ & 1997 & $-5.0409^{*}$ & 1984 & $-4.5962^{*}$ & 2001 & $-4.9143^{*}$ \\
$\mathrm{Y}$ & 1982 & -2.7509 & 1985 & -3.4024 & 1983 & -4.5201 \\
$\Delta \mathrm{Y}$ & 1995 & $-4.9245^{*}$ & 2002 & -4.1316 & 1994 & $-4.9296^{*}$ \\
\hline
\end{tabular}

Note: ${ }^{*}$ indicates significant at the level of significance $5 \%$ or lower.

The structural break points make sense. The period 1983-1985 witnessed a sharp decline in GDP as a result of natural hazards such as low rainfall and desertification, among other factors. The period 1994-2005 was a period of internal and external imbalances. Measures taken by the government to correct these imbalances resulted in substantial improvements in GDP growth.

\subsubsection{Cointegration Tests}

After we have verified that the two series $Y$ and $G$ are integrated of order 1, we now proceed to test whether they are cointegrated. Two different tests are conducted: The Johansen's test and the Engle-Granger test. Tables 3 and 
4 show the results of Johansen's cointegration test. Both the rank and the maximum eigenvalue tests suggest that there is one cointegrating relationship between $G$ and $Y$. This indicates there is indeed a long run causal relationship between $\mathrm{G}$ and $\mathrm{Y}$. However this test does not indicate the direction of the causality between $\mathrm{G}$ and Y.

Table 3. Johansen's Cointegration Test - Trace

\begin{tabular}{lllll}
\hline Hypothesized No. of CE(s) & Eigenvalue & Trace Statistic & 0.05 Critical Value & Prob. $^{* *}$ \\
\hline None ${ }^{*}$ & 0.416341 & 22.27012 & 18.39771 & 0.0137 \\
At most 1 & 0.031916 & 1.265037 & 3.841466 & 0.2607 \\
\hline
\end{tabular}

Note: ${ }^{* *}$ MacKinnon-Haug-Michelis (1999) p-values. The Trace test indicates there is one cointegrating relationship between the two variables.

Table 4. Johansen's Cointegration Test - Maximum Eigenvalue

\begin{tabular}{lllll}
\hline Hypothesized No. of CE(s) & Eigenvalue & Max-Eigen Statistic & 0.05 Critical Value & Prob. $^{* *}$ \\
\hline None $^{*}$ & 0.416431 & 21.00509 & 17.14769 & 0.0131 \\
At most 1 & 0.031916 & 1.265037 & 3.841466 & 0.2607 \\
\hline
\end{tabular}

Note: ${ }^{* *}$ MacKinnon-Haug-Michelis (1999) p-values. The maximum eigenvalue test indicates there is one cointegrating relationship between the two variables.

Table 5. Below shows the Engle-Granger test of Cointegration. The test further confirms the results of the Johansen's cointegration test. The test shows the residuals obtained from the long run relationship are stationary.

Table 5. Engle-Granger Cointegration Test

\begin{tabular}{lllll}
\hline Dependent & Tau-statistic & Prob. $^{*}$ & z-statistic & Prob. $^{{ }^{*}}$ \\
\hline $\mathrm{G}$ & -4.078398 & 0.0448 & -23.91429 & 0.0361 \\
$\mathrm{Y}$ & -2.889211 & 0.3531 & -14.62553 & 0.2990 \\
\hline
\end{tabular}

Note: ${ }^{*}$ MacKinnon (1996) p-values. The Engle-Granger's Cointegration test indicates that the two variables are cointegrated.

Both the Johansen's test and the Engle-Granger test suggest the series are cointegrated. Therefore, we can conclude that there exist a valid long run equilibrium relationship between Y and G. These cointegration tests do not tell direction of the relationship between the variables. The next two sub-sections shed light on the causality between $\mathrm{Y}$ and $\mathrm{G}$.

\subsubsection{The ECM and Granger Causality}

We are now in a position to integrate short-run dynamics with long-run equilibrium. Table 6 shows the results of the estimate of the ECM with the dependent variables being $\Delta \mathrm{G}$ and $\Delta \mathrm{G}$. The coefficient of the error correction term EC(-1) is significant at the 5\% and $10 \%$ levels with the correct negative signs. This suggests the validity of the long relationship between $\mathrm{G}$ and $\mathrm{Y}$. The results also suggest $\mathrm{Y}$ Granger causes $\mathrm{G}$ as the estimated coefficients of $\Delta \mathrm{Y}(-3)$ and $\Delta \mathrm{Y}(-4)$ are also significant at the $10 \%$ and $5 \%$ levels, respectively in the $\Delta \mathrm{G}$ equation. On the other hand, none of lagged $\Delta \mathrm{G}$ variables are significant in the $\Delta \mathrm{Y}$ equation. This suggests that $\mathrm{G}$ does not Granger cause $Y$.

Table 6. Error Correction Model

\begin{tabular}{ccc}
\hline Variable & $\Delta \mathrm{G}$ & $\Delta \mathrm{Y}$ \\
\hline Constant & -0.0294 & $0.0233^{* *}$ \\
$\mathrm{EC}(-1)$ & $-0.2537^{* *}$ & $-0.0742^{*}$ \\
\hline$\Delta \mathrm{G}(-1)$ & -0.0510 & 0.0771 \\
$\Delta \mathrm{G}(-2)$ & -0.1300 & 0.0655 \\
$\Delta \mathrm{G}(-3)$ & $-0.2755^{* *}$ & 0.0545 \\
$\Delta \mathrm{G}(-4)$ & 0.0474 & 0.0445 \\
\hline$\Delta \mathrm{Y}(-1)$ & 0.2086 & $0.2870^{*}$ \\
$\Delta \mathrm{Y}(-2)$ & 03058 & -0.0352 \\
$\Delta \mathrm{Y}(-3)$ & $-0.7793^{*}$ & $0.4600^{* *}$ \\
$\Delta \mathrm{Y}(-4)$ & $1.6445^{* *}$ & 0.1615 \\
\hline$R^{2}$ & 0.49 & 0.37 \\
\hline
\end{tabular}

Note: ${ }^{* *}\left({ }^{*}\right)$ indicates significant at the level of significance $5 \%$ or lower $(10 \%$ or lower). These results indicate Y Granger causes $\mathrm{G}$ and $\mathrm{G}$ does not Granger cause Y. 


\subsubsection{Bivariate Granger Causality Test}

To substantiate the Granger causality test obtained within the ECM above, we also conduct a bivariate Granger causality test. Table 7 shows the result of the pairwise Granger causality test. The test indicates that Y Granger causes G. However, G does not Granger Cause Y. This result, along with results obtained in the ECM, confirm the Wagner hypothesis in the context of Sudan.

Table 7. Pairwise Granger Causality Test

\begin{tabular}{lccc}
\hline Null Hypothesis & Obs & F-Statistic & Prob. \\
\hline Y does not Granger Cause G & 35 & 2.37293 & 0.0640 \\
G does not Granger Cause Y & & 0.73205 & 0.6290 \\
\hline
\end{tabular}

Note: The Granger causality test shows that Y Granger causes G.

\section{Summary and Conclusion}

This paper contributes to the empirical literature on the debate about the validity of the Wagner's hypothesis by using time series data from Sudan. The results clearly support the Wagner hypothesis in the context of Sudan for the period considered. The growth of per capita real GDP has unidirectional relationship with the share of government spending to GDP. In an earlier draft of this paper, a similar conclusion was arrived at using the per capita real GDP and the per capita real government expenditure. So, in other words, the Keynesian theory that increases in government spending result in increases in GDP is not supported by the data from Sudan. Policymakers should be careful about adopting public spending as a policy tool to stimulate the economy.

\section{Acknowledgements}

I acknowledge and appreciate useful comments by two anonymous referees. Any remaining errors are my responsibility.

\section{References}

Barro, R. J. (1991). Economic Growth in a Cross Section of Countries. Quarterly Journal of Economics, 106(2), 407-43. http://dx.doi.org/10.2307/2937943

Dickey, D. A., \& Fuller, W. A. (1981). Likelihood Ratio Statistics for Autoregressive Time Series with a Unit Root. Econometrica, 49(4), 1057-72. http://dx.doi.org/10.2307/1912517

Engle, R. F., \& Granger, C. W. J. (1987). Co-integration and Error Correction: Representation, Estimation, and Testing. Econometrics, 55, 251-76. http://dx.doi.org/10.2307/1913236

Ghali, K. H. (1997). Government Spending and Economic Growth in Saudi Arabia. Journal of Economic Development, 22(2), 165-172.

Granger, C. W. J. (1988). Some Recent Developments in a Concept of Causality. Journal of Econometrics, 39, 199-211. http://dx.doi.org/10.1016/0304-4076(88)90045-0

Granger, C. W. J., \& Newbold, P. (1974). Spurious Regressions in Econometrics. Journal of Econometrics, 2(2), 111-20. http://dx.doi.org/10.1016/0304-4076(74)90034-7

Griger, K. B., \& Tullock, G. (1987). An Empirical Analysis of Cross-National Economic Growth, 1950-1980. Working Paper, California Institute of Technology.

Hsieh, E., \& Lai, K. S. (1994). Government Spending and Economic Growth: the G-7 Experience. Applied Economics, 26, 535-42. http://dx.doi.org/10.1080/00036849400000022

Johansen, Soren. (1991). Estimating and testing cointegration vectors in Gaussian vector autoregressive models. Econometrica, 59, 1551-80.

Kormendi, R. C., \& Meguire, P. G. (1985). Macroeconomic Determinants of Growth: Cross Country Evidence. Journal of Monetary Economics, 16(2), 141-63. http://dx.doi.org/10.1016/0304-3932(85)90027-3

Landau, D. (1983). Government Expenditure and Economic growth: a Cross-Country Study. Southern Economic Journal, 49, 783-92. http://dx.doi.org/10.2307/1058716

Lee, J., \& Strazicich, M. C. (2003). Minimum Lagrange Multiplier Unit Root Test with Two Structural Breaks. The Review of Economics and Statistics, 85(4), 1082-89. http://dx.doi.org/10.1162/003465303772815961

Perron, P. (1989). The great crash, the oil price shock, and the unit root hypothesis. Econometrica, 57, 1361-401. http://dx.doi.org/10.2307/1913712 
Perron, P. (1997). Further Evidence on Breaking Trend Functions in Macroeconomic Variables. Journal of Econometrics, 80(2), 355-85. http://dx.doi.org/10.1016/S0304-4076(97)00049-3

Perron, P., \& Vogelsang, T. J. (1992). Non-stationarity and Level Shifts with an Application to Purchasing Power Parity. Journal of Business \& Economic Statistics, 10(3), 301-20. http://dx.doi.org/10.2307/1391544

Pesaran, M. H., Shin, Y., \& Smith, R. J. (2001). Bounds testing approaches to the analysis of level relationships. Journal of Applied Econometrics, 16, 289-326. http://dx.doi.org/10.1002/jae.616

Philips, P. C. B. (1986). Understanding Spurious Regressions in Econometrics. Journal of Econometrics, 33, 311-40. http://dx.doi.org/10.1016/0304-4076(86)90001-1

Phillips, P. C. B., \& Perron, P. (1988). Testing for a Unit Root in Time Series Regression. Biometrika, 75(2), 335-346. http://dx.doi.org/10.1093/biomet/75.2.335

Ramayandi, A. (2003). Economic Growth and Government Size in Indonesia: Some Lessons for the Local Authorities. Working Paper in Economics and Development Studies, No. 200302.

Sáez, M. P., \& García, S. A. (2006). Government Spending and Economic Growth in the European Union Countries: An Empirical Approach. Working Paper Series (http://ssrn.com/abstract=914104).

Tang, C. F. (2008). A Re-examination of the Relationship between Electricity Consumption and Economic Growth in Malaysia. Energy Policy, 36(8), 3077-85. http://dx.doi.org/10.1016/j.enpol.2008.04.026

Toda, H. Y., \& Yamamoto, T. (1995). Statistical Inference in Vector Auto-regressions with Possibly Integrated Processes. Journal of Econometrics, 66(1-2), 225-50. http://dx.doi.org/10.1016/0304-4076(94)01616-8

United Nations Statistics Division. (2011). National Accounts Main Aggregate Database. United Nations Statistics Division, New York, USA. Available online at http://unstats.un.org/unsd/default.htm

Zivot, E., \& Andrews, D. W. K. (1992). Further Evidence on the Great Crash, the Oil-Price Shock, and the Unit-Root Hypothesis. Journal of Business \& Economic Statistics, 10(3), 251-70. http://dx.doi.org/10.2307/1391541 